\title{
The Electric Church
}

by John L. Mitchell

The growth of religious broadcasting is one of the phenomena of the electronic age. Of roughly 8,000 radio stations in the United States, 1,400 are religious. Of the 800 or so television stations, 30 are religious. Revenues from this religious broadcasting are estimated at about US \$ 500 million a year. The National Religious Broadcasters (NRB), who are predominantly fundamentalist Christians preaching a "Jesus saves" doctrine, estimate that their 900 members reach 129 million radio and television listeners and viewers in the United States. The dominant television evangelical preachers and personalities of the "electric church" are as recognizable on the television scene in the U.S. as are Johnny Carson and Merv Griffin. But they are controversial.

Mainline church groups - Catholic and Protestant - are uneasy with this phenomenon, and at times appear to be waging a "holy war" with the "electric church," as some label these electronic evangelists. Mainline church groups have reason to be uneasy. The electric church is growing, while mainline church groups watch their pews empty. "During the past decade, mainline churches have experienced incipient decline.... And during the same period the electric church has experienced phenomenal growth," says Jeffrey K. Hadden, a University of Virginia sociology professor.

The mainline church groups' growing concern was clearly registered at a conference on the "electric church," held at the State University of New York at Stonybrook, Feb. 6-7, 1980 and sponsored by these groups. No one was sure what the real relationship is between a dwindling mainline church enrollment and the growing "electric church" following. But said Hadden, "there is a very deep concern today that highly successful nationwide television programming is cutting into the pews and treasuries of mainline churches."

Like other electric church officials, Dr. Robert Schuller, host of the popular religious television show, "The Hour of Power," insists they are not drawing members away from local churches. On the contrary, he claims, they encourage local church attendance. "We are meeting profound needs, or we'd be out of business," said Schuller. And he added, "I am judged in the marketplace every Sunday morning," when "The Hour of Power" is aired.

The mainline church groups' criticisms generally follow along these lines: the lack of community orientation; excessive emphasis on personality; the "instant gratification" the TV preachers offer their viewers in place of concern for more complex moral and social issues; the unethical solicitation of money over the air, combined with other commercial marketing techniques; and being too simplistic theologically. A new criticism was added to the list: the inclusion of right-wing political messages in their sermons. Identified as the "Moral Majority," these groups are having a

John L Mitchell M.A. war bis 1973 Leiter der Kommunikationsabteilung der katholischen Sogang Universität Seoul und lehrte an der Chinese University of Hong Kong 1974 bis 1976. Er ist jetzt im Bereich der Satellitenkommunikation in den USA tätig. 
profound impact on the American political process. During the recent presidential election campaign, three "born-again" presidential candidates were carefully monitored by these groups, and fearing to be trapped by their far right positions were constantly kept off balance about endorsing the "moral majority" positions in order to win votes.

The Rev. Jerry Falwell, television evangelist and head of the moral majority, denied that his group is trying to dictate national morality. "We're not trying to jam our moral philosophy down the throats of others. We're simply trying to keep others from jamming their amoral philosophies down our throats ... Moral majority is not an organization of fundamentalists or evangelical people in America. We're a political organization that believes in a pluralistic America operating on a set of moral principles. The one thing we are very much opposed to is the formation ... of a Christian Republic. We have been very much misunderstood along that area."

Still, Rev. Jerry Falwell and his moral majority have done much to raise a new national controversy over the relationship between church and state. And he firmly believes "an amoral minority has gained control of some of the very key parts of government and leadership in America."

Not merely content with attacking political amoralists, Rev. Falwell stirred the anger of the American Jews when he said for publication: "I believe God does not hear the prayers of unredeemed gentiles or Jews." Subsequently he had to recant this statement: "I did not intend to offend anyone with the comment, and I personally believe that God hears and even answers the prayers of the Jews."

Hailed to be the "next Billy Graham," Rev. Falwell invested US \$ 90 to buy half an hour of live television 23 years ago in his home town of Lynchburg, Virginia. When he stopped broadcasting from Lynchburg and changed to a Roanoke, Virginia station a few years ago, it cost him about US $\$ 600$ for the same amount of time. By comparison, Rev. Billy Graham spends US \$ 25 thousand to buy an hour of prime time in New York City for one of his televised crusades.

"Spending for television is a dollar well-spent," claims Falwell confidently. "Most of the country is fed up with the sewers that run through the living rooms from the networks. The fact that industry has monopolized the medium is an indictment against us."

Falwell's revenues for 1978 were about US \$ 32.5 million and were projected to be US $\$ 50$ million in 1979. His weekly television program, "Old-time Gospel Hour," probably the fastest growing of all religious shows, is seen on 320 stations across the U.S. This happens to be more stations than are affiliated with the Columbia Broadcasting System (CBS). His daily radio programs are heard on more than 450 stations, but he expects that number to jump soon to more than 650 . He plans to move one-fourth of his TV programs into prime time and to produce a 90-minute talk show to be aired opposite Johnny Carson. Rev. Falwell projects revenues of US \$ 2 billion a year by 1987-88.

In 1955, Dr. Schuller of Garden Grove, California, was preaching from the roof of a drive-in theatre snack bar to about 50 families in cars. And like a travelling salesman, he moved from door to door "to bring religion to the people," and to 
learn first-hand what their real concerns, religious or otherwise, were. He turned all his experience into a broadcasting crusade. Today, his "Hour of Power" programs are seen on about 130 TV stations, and the programs' annual income is more than US \$ 11 million. His all-glass, star-shaped "Crystal Cathedral“ architecturally is not too far removed in several aspects from the drive-in theatre snack bar he once preached on. It has sliding panels, which allow worshipers in parked cars to see him.

Similar to Schuller's revenues, Rev. Rex Humbard's “Cathedral to Tomorrow” television program had a 1978 budget of US \$ 18 million, which was up US \$ 3.6 million from 1977. His weekly program is taped in Akron, Ohio, and is broadcast on $237 \mathrm{TV}$ stations in the U.S.

One of the most famous TV evangelical types is Rev. Oral Roberts. He is a pentecostal faith-healer, and builds a lavish variety-show around a faith-healing environment. He learned the art of production and dramatic presentation in the National Broadcasting Company's (NBC) studios in Burbank, California, where Johnny Carson now does his shows. Currently, on the campus of Oral Roberts University in Tulsa, Oklahoma, Rev. Roberts does his productions in the fully-equipped facilities there. His studios are considered among the best in the South-west. His operations take in about US $\$ 60$ million a year, and his income is growing at a yearly rate of better than 25 percent. He spends about US $\$ 8$ million per year to broadcast weekly halfhour shows over about 35 stations. His prime-time specials, however, where he is host and his son, Richard, and the World Action Singers appear, are on more than 400 stations.

For more than a year, Rev. Jim Bakker and his show, PTL ("Praise the Lord"), have been attacked in the media for shaky financial dealings. Jim Bakker is a poorman's Johnny Carson, and his program's format follows Carson's, but with a religious emphasis, of course. Like Carson, he is laughing, pleasant, and easy going. In 1972, he left the Pat Robertson's "Christian Broadcasting Network" (CBN) of Virginia Beach, Virginia, to form his own PTL Television Network in Charlotte, North Carolina. The "PTL Club" has an estimated gross income of more than US $\$ 25$ million a year. Lately with an eye on international markets, the PTL is looking into indigenous versions of the program in Japan, Africa, and Italy.

The PTL studios underwrite a US \$ 2 million Spanish program seen in 17 Spanishspeaking countries with a potential viewing audience of 30 million. Another PTL version as been broadcast in Nigeria and Kenya. Others are planned for Asia and Europe. And it's been reported that negotiations for broadcasting the "Spanish Club PTL" in Mexico are complete, even though religious broadcasting is prohibited in Mexico. The Mexican government, however, feels the "PTL Club" is a variety show, not a religious program.

PTL finances other electronic ministries. On their satellite, an RCA Satcom I, they broadcast 24 hours a day of Christian programming, featuring their own programs as well as those of Jerry Falwell, Oral Roberts, James Robison, and Robert Schuller, with no charge to an affiliate. By investing some US $\$ 60,000$ for a receiving dish and transmitter, a local station can hook up to the satellite's free programs and broadcast these pre-recorded Christian programs around the clock.

The electric church officials have a desire, it seems, for big, impressive - and expensive - monuments: Schuller's "Crystal Cathedral," Roberts' Oral Roberts 
University, and Pat Robertson's CBN, for example. Costing US \$ 10 million so far, Jim Bakker has started "Heritage, U.S.A." It is a 1,400 acre tract of land. A massive Polynesian-style pyramid designed to house Heritage University dominates the site. The site will also have a 12-story Polynesian hotel, a clinic, an Old Main Street, a golf course, a high-rise condominium, and a log chalet overlooking a lake. Openair tram vehicles will shuttle guests along the winding asphalt drives to shady hiking spots, an Olympic-sized pool, eight lighted tennis courts, and a barn auditorium seating 2,000, where summer TV programs are taped.

The PTL headquarters in Charlotte is a luxurious mansion, tastefully decorated with chandeliers, a grandfather clock, and oriental rugs over solid mahogany floors. Bakker's office is paneled in mahogany with a black marble hearth on his fireplace. The US $\$ 3$ million studio is one of the best in the world. Besides the mansion, the studio, and the well-equipped offices, this complex now includes a sauna, a massage room, and a remarkable US $\$ 200,000$ swimming pool, which is surrounded by white Grecian columns, arched mirrors, and plastic trailing vines.

Pat Robertson of Virginia Beach, host of "The 700 Club" and founder of the Christian Broadcasting Network (CBN), is another of the video evangelism elite. "The 700 Club" buys time and is aired on 130 stations. It also goes to 3,500 cable TV systems. It is viewed in more than a dozen foreign countries. Robertson took in about US $\$ 59$ million in 1978. He is planning to create a fourth television network with a worldwide organization. CBN is hiring former staff members of the three established networks (ABC, CBS, and NBC) and is broadcasting by satellite. Robertson includes in the plans a full schedule of family viewing, sports, news, movies and drama. This schedule will even have a soap opera called "The Light Inside." Robertson expects the "Continental Broadcasting Network" to reach annual revenues of US $\$ 65$ million within three years. CBN already owns four TV stations, which will become the nucleus of the new network, and six radio stations.

In 1960, Robertson had capital assets of less than US $\$ 70$. He learned of a vandalized and deteriorating UHF TV station for sale in Portsmouth, Virginia. He bought this as well as an FM radio station for virtually nothing. He gave the call letters, WXRI, to the FM radio station, which letters derived from the first letters of the Greek word for "Christ." And he chose WYAH as the call letters for the UHF TV facility, which made it the first TV station to be called by God's name of the Old Testament, "Yahweh." His application for a license with the Federal Communications Commission (FCC) was the first in FCC history' asking to devote more than 50 percent of its broadcast time to religious programming.

In the fall of 1963 , Robertson decided to hold a telethon as a way to get money to keep his operation going. He had calculated that he needed US $\$ 7,000$ a month to meet expenses. So he appealed for 700 people to pledge US $\$ 10$ each month. He called the telethon "The 700 Club." The telethon succeeded in giving Robertson only half the needed amount, but it gave him the name of his TV program, which has been so successful eversince. The many people who called during the telethon appreciated the opportunity to telephone during the broadcast and liked the loose variety-show-and-interview format. They asked that the production continue and incorporate these features. 
More of a Merv Griffin than a Johnny Carson, Pat Robertson sits behind a typical talk-show desk and allows his guests to tell wondrous stories of conversion and miracle. Besides such notable interview coups as with Jimmy Carter und former Israeli Prime Minister Yitshak Rabin, Robertson interviews a never-ending stream of scientists, scholars, judges, athletes, authors, pastors, missionaries, military officers, prisoners, and even pizza cooks, all of whom attest to the mighty acts of God in their lives. As they tell of their own deliverance from an empty life, or of battles being waged against pornography, abortion, homosexuality and occult movements, or of the latest developments in the search of Noah's Ark, or of the harvest among the heathen in faraway lands across the sea, Pat Robertson spurs them on with ecstatic whispers of "Yessss," "Praise God!" and "Do it, Lord!"

The interviews are interspersed with live and taped musical segments - mostly by artists, who, though talented, would not be on national television had they not accepted Jesus as their personal savior - and with reports coming in from the audience by telephone. Beginning with the 1963 telethon, "The $700 \mathrm{Club"} \mathrm{pio-}$ neered "two-way television" by inviting viewers to share their problems and concerns with telephone counselors. In 1977, the national center at CBN headquarters handled over a million calls and hundreds of thousands more came into approximately 60 local centers throughout the United States, all operating on an aroundthe-clock basis and staffed by over 7,000 trained counselors. Thus, throughout the broadcasts, viewers hear ringing phones and muffled conversations and get an occasional glimpse of counselors earnestly talking to or praying with callers.

Not least among the "wondrous things" associated with "The 700 Club" is the growth of its parent network. In addition to the stations it owns, CBN has affiliation agreements with approximately 90 additional television and 120 radio stations that wish to be part of the fourth network. Robertson acknowledges that the notion of challenging the major networks makes him feel a bit like David striding out to meet Goliath. But by using the RCA SATCOM satellite, he can reach some 60 top markets in the U.S. He first used satellite facilities in August, 1977, when he featured live telecasts from five continents, culminating in a shot of the Mount of Olives in Jerusalem. By the end of 1977, CBN had already established itself as the largest syndication of satellite-transmitted programs in the U.S. Compared to his 1963 telethon, his 1978 nationwide telethon raised US $\$ 750,000$ in gifts and pledges in a seven-day period.

Robertson expects to supply his affiliates with as much as 40 hours of programming a week. Mostly this programming would be religious programs produced by $\mathrm{CBN}$, but would also include wholesome variety shows, situation comedies, sports, and perhaps a Christian soap opera. He also expects his news programming to emphasize hard-hitting investigative reporting and show "some of the good news, the very wonderful and wholesome activities from the heartland of America that deserve to be brought to the attention of our people."

To make sure the Lord's electronic vineyards will have plenty of qualified workmen to trample out the vintage, Robertson's CBN University's new graduate institution will offer a master's degree in communications and theology, with programs in music, drama, business, government, and law expected to follow. He anticipates an enrollment of 1,000 students. The university will be located in the CBN Center, a US \$ 20 million complex under construction on a 187-acre site in Virginia Beach. 
The dominant structure of the complex, a massive 170,000 square-foot colonial Georgian building in the shape of a cross, will house the network's corporate offices, four television studios, satellite communications facilities, a prayer chapel, a linguistic center for translating programs into various foreign languages, and the international prayer and counseling center. The complex will also include facilities for CBN university Press and Continental Picture Corporation, a film company that will produce Christian-oriented films on the order of those produced by Billy Graham's Worldwide Pictures.

Most of the money to pay for these ventures comes in small to moderate amounts from individuals and families, not all of whom are given from a superfluity of abundance. To supplement these gifts, CBN also generates substantial income from an investment program that pays up to eight percent on savings accounts that revert to the ministry upon the death of the depositor. The budget for CBN operations has grown almost geometrically, from the barebone days of the early ' 60 s to US \$ 1 million in 1971, to an estimated US \$ 10 million in 1975 and US \$ 20 million in 1977.

Asked why, in his opinion, so much media coverage of religious broadcasting has been negative or cynical, Robertson replied: "Many who write about religion feel that if someone goes into the jungle like Albert Schweitzer or lives with the birds like Saint Francis of Assisi, he is okay, but if he wears a business suit and has a staff and does what is needed to reach people in today's civilized world, they are immediately awed by the numbers involved and assume something is wrong. They have a stereotyped image of what they think a holy man should be like and if he doesn't fit that image, something must be wrong. ... They can see taking US \$ 100 million and feeding some hungry people, but they can't see using that money for the communication of thought. People have to understand that intangibles are of value. Truth is a thing of value, virtue is a thing of value, peace and long-suffering and mercy and gentleness - these are of great value to the nation, and the only way they can be transmitted is through the spoken word, and to do that in a high-speed, fastmoving, industrialized society requires large sums of money relative to the costs of running the little brown church in the wildwood."

"The mainline denominations are running scared," said Schuller. "They're losing ground because they fail to meet the deepest emotional needs of people." Schuller and Robertson argue that their programs help meet those needs and provide their viewers with spiritual nourishment. While many at the conference disagreed with that assessment, they felt the mainline churches would soon be following the video evangelicals onto television.

Dr. Robert Liebert, a psychiatry and psychology professor of the State University of New York at Stonybrook, predicted the electric church will continue to grow, but in unforeseen directions. "I predict that the electric denominations, far from drawing people away from the pews, will in this decade build the pews themselves. ... I envision each electric denomination setting up local community centers, with an absolute philosophic and economic tie to the denomination's charismatic leader.... The electric church got its start in broadcasting, but it is not merely airwave religion." 


\section{Bibliography}

\section{Papers:}

Papers from the National Council of Churches' Communications Commission's "Consultation on 'The Electronis Church', , held at the State University of New York at Stonybrook, Feb. 6-7, 1980:

Dr. Jeffrey K. Hadden:

Dr. Robert Liebert:

Rev. Charles Swann:

Articles:

Philip Yancey:

Charles E. Swann:

Martin E. Marty:

Ben Armstrong:

James A. Taylor:

Tom Bethell:

George Gerbner:

Gerbner:

Book:

Ben Armstrong:
Some Sociological Reflections on the Electronic Church.

The Psychological Attractions of the Electronic Church.

The Varieties and Appeals of the Electronic Church.

The Ironies and Impact of PTL. "Christianity Today", Sept. 21, 1979, pp. 1250-1254.

The Electric Church, "Presbyterian Survey", May 1979. pp. 9-16.

The Invisible Religion, ibid., p. 13.

Does the Electric Church Hurt the Local Church? "Religious Broadcasting", July, 1979, pp. 19-20. and pp. 41-43;

If you can't beat 'em, join 'em, "Broadcasting", Feb. 18, 1980, pp. 118 and 122;

The Electric Church, "The Wall Street Journal", Friday, May 19, 1978. Vol. XCVIII, No. 98 p. 1.

Progeny of Programmers: Evangelical Religion and the Television Age, "The Christian Century", (April 20, 1977);

Pat Robertson and CBS, "Broadcasting" (Mar. 6, 1978) pp. 56-68.

Fourth Estate: 'National Religious Broadcasters Convention,' "Harper's" (Apr. 1978) p. 86.

Television: The New State Religion? "Etcetera" (June, 1977), pp. 145-50.

Television As New Religion, "New Catholic World," (Mar/Apr. 1978), pp. 52-56.

The Electric Church, New York: Thomas Nelson, Inc. Publishers, 1979. 


\section{ZUSAMMENFASSUNG}

Das Wachsen religiösen Rundfunks in den Vereinigten Staaten ist ein Zeichen unseres elektronischen Zeitalters: Von rund 8.000 Hörfunkanstalten der Staaten haben 1.400 eine religiöse Bindung und von den 800 Fernsehsendern sind es dreißig. Das Einkommen von religiösen Sendungen wird auf 500.000.000,- US-Dollar, also etwa eine Milliarde DM jährlich geschätzt. Die hauptsächlich fundamentalistisch geprägte Vereinigung der Nationalen Religiösen Rundfunkleute (NRB) schätzt, daß sie durch ihre 900 Mitglieder 129.000.000 Menschen in den USA erreicht. Beunruhigend für die großen Kirchen - Katholiken und Protestanten ist bei dieser Entwicklung, daß ihr Anteil an diesem Phänomen sinkt, während die sogenannte „elektronische Kirche“ ein erstaunliches Wachstum verzeichnet. Die Sorge der großen Kirchen wurde sehr deutlich auf einer Konferenz über die „elektronische Kirche“ am 6. und 7. Februar 1980 in New York ausgesprochen. Ähnlich wie andere Vertreter der elektronischen Kirche behauptet Dr. Robert Schuller, Leiter der „Hour of Power“, daß sie nicht nur keine Mitglieder von den großen Kirchen abwerben, sondern sie im Gegenteil zur Teilnahme am örtlichen Gottesdienst führen ...

Die Kritik der großen Kirchen nennt meistens folgende Punkte für die „elektronische Kirche": das Fehlen einer Gemeindeorientierung, übertriebene Betonung einer leitenden Persönlichkeit, die „sofortige Erfüllung “, die vom Veranstalter statt einer detaillierten Betrachtung geboten wird, die Bitte um Geld, zusammen mit anderen kommerziellen Aktivitäten und eine zu sehr vereinfachende Theologie. Hinzu kommen neuerdings auch stark rechts angesiedelte politische Überlegungen. Fernsehevangelist Jerry Falwell bestreitet, daß seine Gruppe „Moral majority“ nationale Moral diktieren will.

Als der „zweite Billy Graham“ begann Falwell vor 23 Jahren mit einer halben Stunde Fernsehprogramm für 90,- US-Dollar in seiner Heimat Lynchburg, Virginia. Als er vor einigen Jahren von dort nach Roanoke, Virginia übersiedelte, kostete ihn die gleiche Sendezeit 600,US-Dollar, während Billy Graham für eine Stunde beste Sendezeit in New York 25.000,US-Dollar für einen seiner Fernsehkreuzzüge zahlte. Im Jahre 1978 beliefen sich Falwells Einkünfte auf 32,5 Millionen US-Dollar, und für 1979 wurden ganze 50 Millionen erwartet. Sein wöchentliches Fernsehprogramm „Old Time Gospel Hour“ ist das am schnellsten wachsende Programm dieser Art, das inzwischen über 320 Sender ausgestrahlt wird. Dies sind mehr Fernsehsender, als zum großen Netz des nationalen "Columbia Broadcasting System“ (CBS) gehören. Sein tägliches Hörfunkprogramm läuft über 450 , soll aber bald 600 Stationen erreichen.

Dr. Schuller begann 1955 als Prediger vom Dach eines „Drive-In Theaters“ in Garden Grove, Kalifornien. Er ging wie ein Kaufmann von Tür zu Tür und erfuhr so die Sorgen der Leute. Diese Erfahrung brachte er in einen Rundfunkkreuzzug ein, „The Hour of Power", dessen Programme über etwa 130 Fernsehstationen zu sehen sind und die jährlich etwa 11 Millionen US-Dollar einbringen. Ähnlich den Einkünften Schullers hatte Rex Humbard mit seinem Fernsehprogramm „Kathedrale von Morgen“, das über 237 Fernsehsender geht, 1978 ein Budget von 18 Millionen US-Dollar. Einer der berühmtesten Fernsehevangelisten ist Oral Roberts. Er ist Pfingstler und „Glaubensheiler", der sein Programm als Show um die Heilungsgeschehnisse aufbaut. Er erlernte Fernsehproduktion und dramaturgische Präsentation bej der National Broadcasting Company (NBC). Die Programme werden jetzt in den Studios einer nach ihm benannten Universität mit einem Volumen von jährlich 60 Millionen USDollar produziert. Das jährliche Wachstum wird mit $25 \%$ angegeben.

Seit über einem Jahr werden Rev. Jim Baker und seine PTL („Praise the Lord“) Show in den Medien wegen ihres finanziellen Verhaltens angegriffen. Das Einkommen seines „PTL-Club's“ wird auf 25 Millionen US-Dollar pro Jahr geschätzt. Im übrigen plant er eigene Versionen seiner Show für Japan, Afrika und Italien. Die PTL-Studios haben ein spanisches Programm (2.000.000,- US-Dollar), das in 17 spanischsprechenden Ländern von rund 
30.000 Menschen gesehen wird. Andere eigene Versionen wurden für Nigeria und Kenia produziert. PTL finanziert andere elektronische Dienste, so ein 24-stündiges religiöses Programm über Satellit, das auch die Produktionen anderer „elektronischer Evangelisten“ benutzt. Mit einer Investition von 60.000,- US-Dollar für Empfänger und Sender kann jede lokale Radiostation sich diesem Satellitenprogramm ohne weitere Kosten zur freien Nutzung über 24 Stunden anschließen. Die Vertreter der „elektronischen Kirche“ haben im übrigen Interesse an großen, eindrucksvollen und teueren Unternehmungen wie Schullers „KristallKathedrale“, Roberts „Oral Roberts Universität“ . . Das 3.000.000,- US-Dollar PTL-Studio in Charlotte ist eines der besten der Welt.

Pat Robertson ist ein anderer der elektronischen Elite (Einkommen 1978: ca. 58 Millionen USDollar). Er ist Begründer des „Christian Broadcasting Network“ (CBN) und in seinem Talk-

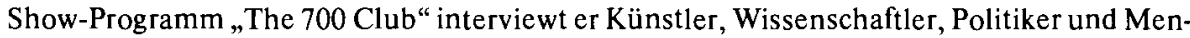
schen aller Lebensalter und Berufe, die außerdem in die Sendung hineintelefonieren können. So erhielt die nationale Zentrale 1977 über eine Million Anrufe und die 60 lokalen Zentren im Lande mit über 7.000 ausgebildeten Beratern hatten tausende von weiteren Anrufen. CBN hat außer den eigenen Stationen Affiliationsverträge mit über 90 zusätzlichen Fernseh-und 120 Hörfunksendern, die in Zukunft zu einem vierten nationalen Netz zusammengeschlossen werden sollen. Robertson benutzte 1977 zuerst die Möglichkeiten der Satellitenkommunikation für seine Unternehmen. Auch für Nachwuchs ist gesorgt. RobertsonCBN-Universität hat eine neue Hochschulabteilung mit einem Magisterprogramm in Kommunikation und Theologie, denen weitere Abteilungen in einem riesigen 20 Millionen USDollar Komplex in Virginia Beach folgen sollen.

Das meiste Geld für alle diese Unternehmungen kommt in kleinen Summen, von Einzelnen und Familien, oft einfachen Leuten. Diese Einkünfte werden bei CBN durch ein großes Investitionsprogramm mit Einkünften von Sparkonten, die bei $8 \%$ nach dem Tod eines Inhabers dem Werk übergeben werden, wachsen.

Die „elektronischen“ Evangelisten sagen, daß sie den Menschen in seiner heutigen zivilisierten Welt abholen und sein Bedürfnis für Werte und Emotionen und geistiger Nahrung erfüllen, was offensichtlich den großen Kirchen nicht gelingt. Nach Meinung des Psychiaters und Psychologen Robert Liebert wird es aber bei den „elektronischen Kirchen" des Rundfunks nicht bleiben. Sie werden von ihren Zentren aus eigene Organisationen mit eigener Philosophie und Anhängerschaft an den charismatischen Führer bilden.

\section{RÉSUMÉ}

Aus Etats-Unis, l'époque électronique a conduit à une croissance, pour nous inimaginable, des émissions religieuses radio-diffusées, pour ainsi dire à une Eglise "électrique» ou «électronique» qui continue à grandir et à prendre de l'influence. Aux USA, on estime atteindre 129 millions d'hommes avec des émissions religieuses, grâce à 1.400 de 8.000 stations de radio et 30 des 800 émetteurs de télévision. L'«Eglise électronique» donne de sérieux soucis aux grandes Eglises à cause de sa manière de voir fondamentalement empreinte: aucune orientation à une communauté, la trop grande insistance de la personnalité dirigeante, le bon augure immédiat, la théologie simplifiée et la forte commercialisation ainsi formulent-elles leurs réserves. En face de cela, les évangélistes de cette «Eglise électronique» mettent l'accent sur le fait qu'ils vont chercher l'homme dans son monde actuel et réalisent ses véritables besoins, ce qui ne réussit visiblement pas aux grandes Eglises. Entre-temps, l'«Eglise électronique» essaie d'étendre son influence également aux autres continents. 


\section{RESUMEN}

En Estados Unidos, la era electrónica ha contribuído a un increíble desarrollo de las emisiones radiofónicas religiosas o, por decirlo de otro modo, al desarrollo de una Iglesia "eléctrica" o «electrónica», que sigue creciendo y gana cada día en influencia. Unos 129 millones de personas escuchan en Estados Unidos los programas religiosos difundidos por 1.400 de las 8.000 emisoras de radio y por 30 de las 800 emisoras de televisión. Por su postura fundamentalista, la «Iglesia electrónica» preocupa a las grandes Iglesias tradicionales, que critican en el nuevo fenómeno la falta de estructura comunitaria, la acentuación del carisma de las personalidades dirigentes, la promesa de felicidad inmediata, la simplificación de la teología y la comercialización de lo religioso. A su vez, los evangelistas de la «Iglesia electrónica» subrayan que ellos contactan con el hombre en el mundo actual, lo cual no siempre ocurre, insinúan, en las grandes Iglesias. Mientras tanto, la «Iglesia electrónica» trata de contactar también con los hombres en otras partes del mundo. 